\title{
TINJAUAN TEOLOGIS TENTANG MIMPI BERDASARKAN \\ KITAB KEJADIAN 37:1-11 DAN RELEVANSINYA DALAM KEHIDUPAN ORANG PERCAYA MASA KINI
}

\author{
Fini Ardila ${ }^{1}$ \\ sttjaffraymakassar@yahoo.co.id
}

\begin{abstract}
ABSTRAK
Tujuan penulisan karya ilmiah ini adalah: Pertama, untuk memberikan pemahaman teologis tentang mimpi berdasarkan kitab Kejadian 37:1-11. Kedua, untuk menjelaskan relevansi mimpi bagi kehidupan orang percaya masa kini.

Dalam penulisan karya ilmiah ini metode penelitian yang digunakan antara lain adalah: Pertama, metode penulisan Hermeneutik. Kedua, eksegesis. Ketiga, metode kepustakaan. Keempat, metode analisis data dalam karya ilmiah ini menggunakan metode interpretasi. Hal ini didasarkan pada analisis kitab dengan menggunakan pendekatan hermeneutik eksegesis pada kitab Kejadian 37:1-11.

Berdasarkan hasil uraian penulis dalam karya ilmiah tentang tinjuan teologis tentang mimpi berdasarkan kitab Kejadian 37:1-11 maka penulis menarik kesimpulan sebagai berikut: Pertama, mimpi adalah alat penyataan Allah, di mana dalam penglihatan itu Allah menyampaikan informasi, memberikan petunjuk dan memimpin umat-Nya kepada jalan yang Allah kehendaki. Kedua, Allah berkomunikasi kepada manusia bukan hanya kepada orang-orang dalam Perjanjian Lama tetapi zaman sekarang pun Allah masih menggunakan mimpi sebagai sarana untuk berkomunikasi kepada manusia untuk memperingati dan menyampaikan maksud Allah kepada manusia. Ketiga, Allah berbicara kepada manusia dalam mimpi, sehingga manusia lebih mengenal bahwa Allah berdaulat memberikan informasi tentang masa depan seseorang. Keempat, melalui penglihatan, Allah memberikan peringatan-peringatan kepada manusia. Memperingati orang-orang tertentu yang hidupnya tidak berkenan kepada Allah, sehingga orang tersebut bertobat. Kelima, Allah bisa menyampaikan maksudnya kepada manusia bisa bersifat pribadi dan bersifat universal. Keenam, Mimpi dapat digunakan oleh Allah untuk menyatakan visi bagi orang-orang tertentu dengan memberikan suatu penglihatan akan masa depannya.
\end{abstract}

Kata Kunci: mimpi, Kejadian 37:1-11

${ }^{1}$ Alumni SI STT Jaffray 2013. 


\section{PENDAHULUAN}

\section{Latar Belakang Masalah}

Mimpi adalah hal yang lumrah dan pasti pernah dialami oleh manusia, baik mimpi yang indah maupun mimpi yang buruk dan tanpa disadari kadangkala peristiwa yang dialami dalam mimpi itu benarbenar menjadi kenyataan di dalam kehidupan manusia. Dalam kehidupan sebagian orang percaya jarang untuk mempercayai sebuah mimpi dan mengabaikan mimpi itu, tetapi tidak dapat dipungkiri pada kenyataannya orang Kristen juga ada yang mempercayai peristiwaperistiwa yang terjadi dalam mimpi.

Zaman modern ini begitu banyak orang yang mencari arti mimpinya dengan datang kepada peramal dan melalui dunia maya bahkan ada yang memiliki bisnis dengan memberi rujukan nomor togel atau untuk mendapatkan rejeki, seperti yang dikatakan oleh G. William Domhoff, "mimpi dapat digunakan untuk menemukan permainan, memprediksi cuaca, atau bernubuat tentang masa depan." Orang-orang yang berusaha mencari arti mimpi ini bukan hanya orang-orang duniawi tetapi orang percaya pun demikian. Hal ini merupakan tanggung jawab hamba-hamba Tuhan dan pemimpin gereja untuk memberikan sebuah pengajaran yang benar tentang mimpi bagi kehidupan orang percaya pada masa kini.

Alkitab mencatat dua macam jenis mimpi. Yang pertama, "mimpimimpi yang mencirikan mimpi biasa, si pemimpi melihat sederet sosok atau makna yang berhubungan dengan peristiwa-peristiwa dalam hidup sehari-hari (Kejadian 40:9-17; 41:1-7). Kedua, mimpi-mimpi yang memberitakan kepada si pemimpi itu suatu berita dari Allah (Kejadian 20:3-7; 1 Raja-Raja 3:5-15; Matius 1:20-24; Kisah Para Rasul 18:9-10).” Meskipun demikian, tidak semua mimpi yang dialami oleh manusia datangnya dari Tuhan.

Ayat-ayat Alkitab khususnya dalam Perjanjian Lama yang membahas tentang Allah hadir dalam mimpi untuk menyampaikan suatu nubuatan kepada manusia tentu semuanya memiliki makna teologis, namun penulis melihat makna teologis dalam kisah tentang pribadi Yusuf yang mendapat mimpi tentang rencana Allah berupa nubuat bagi masa depan Yusuf dan keluarganya dalam Kejadian 37:1-11 ini lebih

\footnotetext{
${ }^{2}$ G. William Domhoff, "Dreamsearch," diakses tanggal 09 April 2013; tersedia di http"//www.ucsc. edu/dreams/library/purpose.html. 1995), 86

${ }^{3}$ Ensiklopedi Alkitab Masa Kini Jilid II (Jakarta: Yayasan Komunikasi bina Kasih,
} 
mudah dipahami serta mimpi yang dialami Yusuf pun benar-benar terjadi. Perjanjian Lama terbukti Allah sering menyatakan diri-Nya dan rencana kepada manusia melalui sebuah mimpi. Kesimpulan dari permasalahan di atas banyaknya orang percaya yang mengalami mimpi yang selalu dikaitkan dengan hal spiritual, dengan menganggap mimpi itu datangnya dari Tuhan tanpa memahami makna teologisnya dengan benar. Berdasarkan masalah yang terjadi, maka penulis merasa perlu membahasnya di bawah satu judul karya ilmiah, yaitu: "Tinjauan Teologis Tentang Mimpi Berdasarkan Kitab Kejadian 37:1-11 dan Relevansinya Dalam Kehidupan Orang Percaya Masa Kini."

\section{Pokok Masalah}

Berdasarkan Latar belakang masalah di atas, masalah pokok yang akan dibahas dalam penulisan karya ilmiah ini adalah:

Pertama, apakah makna mimpi berdasarkan kitab Kejadian 37:1-11. Kedua, apakah relevansi mimpi bagi kehidupan orang percaya masa kini.

\section{Tujuan Penulisan}

Adapun yang menjadi tujuan penulisan karya ilmiah ini adalah:

Pertama, untuk memberikan pemahaman teologis tentang mimpi berdasarkan kitab Kejadian 37:1-11. Kedua, untuk menjelaskan relevansi mimpi bagi kehidupan orang percaya masa kini.

\section{Manfaat Penulisan}

Penulisan karya ilmiah ini diharapkan akan memberi manfaat yang baik kepada pembaca. Adapun manfaat penulisan karya ilmiah ini adalah: Pertama, agar menambah wawasan pembaca mengenai mimpi. Kedua, agar dapat menjadi dasar Alkitabiah dalam pengajaran tentang mimpi.

\section{Metode Penulisan}

Dalam penulisan karya ilmiah ini metode penelitian yang digunakan antara lain adalah:

Pertama, metode penulisan Hermeneutik. Kedua, eksegese adalah sebuah istilah yang dapat kita artikan sebagai suatu usaha untuk menafsirkan sesuatu. Ketiga, dalam penulisan karya ilmiah ini metode pengumpulan data yang digunakan adalah metode kepustakaan (library research), yaitu menggunakan Alkitab, kamus, tafsiran dan buku-buku serta berbagai tulisan-tulisan yang terdapat di media online yang berhubungan dengan pembahasan dalam karya ilmiah penulis. Keempat, 
metode analisis data dalam karya ilmiah ini menggunakan metode interpretasi. Hal ini didasarkan pada analisis kitab dengan menggunakan pendekatan hermeneutik eksegesis pada kitab Kejadian 37:1-11.

\section{Batasan Penulisan}

Dalam penulisan karya ilmiah ini, penulis hanya membahas tentang mimpi berdasarkan Kejadian 37 dan relevansinya dalam kehidupan orang percaya masa kini.

\section{EKSEGESIS KITAB KEJADIAN 37:1-11 TENTANG MIMPI}

\section{Latar Belakang Konteks Kejadian 37:1-11}

Konteks Kejadian 37:1-11, ayat 1 memperkenalkan keturunan atau riwayat keluarga Yakub di Kanaan dimulai dengan generasi Yakub, keluarga Yakub tinggal di tanah penumpangan ayahnya, tanah Kanaan. Allah memberkati mereka secara materi, Abraham dengan iman berada di tanah yang dijanjikan Allah kepadanya bahkan keturunannya bisa menduduki tanah Kanaan. Melihat latar belakang keturunan Yakub, dapat dilihat di tanah Kanaan ini dimulai satu generasi yang baru yaitu Yusuf dan kakaknya. Ayat 2 menjelaskan tentang usia Yusuf waktu itu, yakni tujuh belas tahun. Yusuf mendapat mimpi di mana isi mimpinya itu memperlihatkan masa depan Yusuf dan keluarganya. Yune Sun Park mengatakan bahwa, "dua mimpi yang ditulis di sini menggambarkan bahwa Yusuf akan lebih tinggi daripada saudara-saudaranya dan orang tuanya. Mimpi ini tidak terjadi karena kebetulan, tetapi oleh campur tangan Allah." ${ }^{4}$ Makna mimpi dalam konteks Yusuf ini adalah bersifat profetik yaitu suatu penglihatan atau nubuatan tentang diri Yusuf sendiri yang akan menjadi pemimpin besar di mana saudara-saudaranya dan kedua orang tuanya pun akan sujud menyembah dengan mukanya sampai ke tanah.

\section{Genre Naratif Kejadian 37:1-11}

Genre adalah istilah "bahasa Perancis yang menyatakan perbedaan jenis tulisan. Arti pokok dari istilah ini adalah pembagian dari bentukbentuk tulisan ke dalam kategori-kategori yang memiliki sifat yang sama; cerita sejarah, puisi, amsal, wahyu dan perundangan." Khususnya kitab Kejadian 37:1-1l bergenre naratif. Narasi adalah "pengisahan satu

\footnotetext{
${ }^{4}$ Yune Sun Park, Tafsiran Kitab Kejadian (Batu Malang: YPPI, 2002), 244-245.

${ }^{5}$ Bob Utley, Anda Dapat Memahami Alkitab keunggulan Perjanjian Baru: Wahyu (Texas Bible Lesson Internasional, Marsall, 1999), 230.
} 
cerita atau kejadian," ${ }^{6}$ atau berisikan penjelasan suatu peristiwa atau kejadian. Penafsiran narasi mengacu kepada bagian-bagian kitab di dalam Alkitab atau bagian-bagiannya sebagai sebuah kesusastraan yang utuh dengan memusatkan perhatian pada tokoh, alur, latar, dan sudut pandang. ${ }^{\top}$ Dengan fokus seperti itu, tepatlah bila dikatakan bahwa naratif memperhatikan apa yang dikatakan teks dan bagaimana mengatakannya untuk menimbulkan respons tertentu dari pembaca, ${ }^{8}$ supaya dalam menganalisis komponen-komponen tersebut, nuansa teks dan akibatnya pada pembaca akan dapat dipahami. ${ }^{9}$ Narasi berkaitan dengan hikayat karena mengandung cerita, hikayat berarti "karya sastra berbentuk prosa yang berisi cerita." ${ }^{10}$ Cerita tentang kisah Yusuf ini mengandung cerita yang nyata atau fakta yang telah terjadi, dan bukan suatu hayalan.

\section{Analisa Narasi Kejadian 37:1-11 \\ Narator Dalam Kejadian 37:1-11}

Dalam Kejadian 37:1-11 narator mengetahui keturunan Yakub yang tinggal menumpang di tanah Kanaan (37:1), narator mengetahui umur Yusuf dan pekerjaan Yusuf sebagai pengembala kambing domba (37:2), narator mengetahui bahwa Yakub lebih mengasihi Yusuf (37:3-4). Narator mengetahui Allah menyampaikan suatu nubuat kepada Yusuf melalui mimpi (37:5-6) dan respon saudara-saudara Yusuf tentang mimpi yang diceritakan oleh Yusuf kepada mereka (37:8-9a). Narator mengetahui Allah berdaulat memberikan lambang dalam mimpi Yusuf (berkas-berkas gandum, matahari, bulan, dan sebelas bintang) (37:6,9b). Narator mengetahui respon iri hati yang timbul di hati saudarasaudaranya dan narator mengetahui bahwa Yakub dengan diam-diam menyimpan perkataan Yusuf tentang mimpi yang dialaminya (37:10-11).

${ }^{6}$ Kamus Besar Bahasa Indonesia, s.v. "narasi."

${ }^{7}$ Janice Capel Anderson and Stepen Moore, Mark \& Method: New Approaches in Biblical Studies (Chattanooga: Precept Ministries, 1992), 165. Dikutip oleh Andreas B. Subagyo, Pengantar Riset Kuantitatif dan Kualitatif (Bandung: Kalam Hidup, 2004), 132-133.

"Alan Culpepper, A Literary Model" dalam Raymond Bailey (Contributing Editor), Hermeneutics for Preaching: Approaches to Contemporary Interprations for Preaching (Nashville: Broadman Press, 1992), 78. Dikutip oleh Subagyo, Pengantar Riset Kuantitatif \& kualitatif, 133.

${ }^{9}$ Janice Capel Anderson and Stepen Moore, Mark o Method: New Approaches in Biblical Studies (Chattanooga: Precept Ministries, 1992), 164. Dikutip oleh Andreas B. Subagyo, Pengantar Riset Kuantitatif \& Kualitatif (Bandung: Kalam Hidup, 2004), 133.

${ }^{10}$ Kamus Besar Bahasa Indonesia, s.v. "hikayat." 


\section{Waktu Cerita Dalam Kitab Kejadian 37:1-11}

Waktu yang digunakan dengan peristiwa-peristiwa dalam narasi Kejadian 37:1-11 adalah sebagai berikut:

1. Yakub tinggal di penumpangan tanah Kanaan (37:1).

2. Yusuf pada waktu itu berumur 17 tahun (37:2).

3. Pada masa muda Yusuf menggembalakan kambing domba bersama saudara-saudaranya (37:2).

4. Di usia 17 tahun, Yusuf mendapat dua mimpi yang berbeda, mimpi yang pertama, sebelas berkas gandum saudara-saudaranya mengelilingi dan sujud menyembah kepada berkas gandum Yusuf $(37: 7)$.

5. Mimpi yang kedua, Yusuf melihat matahari, bulan, dan sebelas bintang sujud menyembah kepadanya (37:9).

Waktu yang ada ini menunjukkan bahwa pada waktu peristiwa ini terjadi keluarga Yakub tinggal di penumpangan tanah Kanaan, karena tanah Kanaan adalah tanah yang dijanjikan Allah kepada keturunan Abraham, Ishak, dan melalui mimpi Yakub dalam Kejadian 28:13-15 Allah membuat Yakub kembali ke tanah Kanaan. Di usia 17 tahun Yusuf mendapat dua mimpi yang berbeda tetapi dengan makna yang sama.

\section{Plot dan Adegan Kitab Kejadian 37:1-11}

"Plot adalah alur cerita, karena setiap cerita harus mempunyai awal, pertengahan, dan akhir. Plot ini menelusuri perkembangan peristiwa, penyebabnya, dan episode-episode yang muncul dalam cerita."

Adegan adalah "menggambarkan sesuatu yang terjadi pada waktu atau tempat tertentu, setiap adegan terdiri dari dua tokoh atau lebih." ${ }^{\text {,2 }}$ "Pembagian adegan terdiri dari waktu, setting (tempat, ciri-ciri lingkungan, dan para tokoh), dan mode narasinya (melalui komentar penulis, dekarya ilmiah langsung dan narasi dramatis." 3

Kitab Kejadian 37:1-1l dibagi menjadi enam adegan dalam tiga alur cerita yaitu:

\footnotetext{
${ }^{11}$ Kaiser, Jr, Berkhotbah dan Mengajar dari Perjanjian Lama (Bandung: Yayasan Kalam Hidup, 2009), 85-86.

${ }^{12}$ Ibid., 85-86.

${ }^{13}$ Richard L. Pratt, Jr, Ia Berikan Kita Kisah-Nya (Surabaya: Momentum, 2005), 175-181.
} 
Tabel 1: Pembagian Adegan dan Plot

\begin{tabular}{|c|c|c|}
\hline Ayat & Adegan & \multirow{3}{*}{$\begin{array}{c}\text { Plot } \\
\text { Bagian Awal: Riwayat keluarga } \\
\text { Yakub }\end{array}$} \\
\hline $37: 1-3$ & Pertama & \\
\hline $37: 4$ & Kedua & \\
\hline $37: 5-7$ & Ketiga & \multirow{2}{*}{$\begin{array}{l}\text { Bagian Tengah:Yusuf mendapat } \\
\text { mimpi yang pertama }\end{array}$} \\
\hline $37: 8$ & Keempat & \\
\hline $37: 9$ & Kelima & \multirow[t]{2}{*}{$\begin{array}{l}\text { Bagian Akhir: } \\
\text { Yusuf mendapat mimpi yang kedua }\end{array}$} \\
\hline $37: 10-11$ & Keenam & \\
\hline
\end{tabular}

\section{Pengulangan dan Kata Kunci Kejadian 37:1-11}

Kata-kata penting dalam Kejadian 37:1-11 adalah:

1. Mengasihi (אָָה - ahav) menunjukkan bahwa Yakub lebih mengasihi Yusuf daripada anak-anaknya yang lain (37:3-4), karena Yusuf anaknya yang lahir pada masa tuanya.

2. Benci (w - syane) menunjukkan kebencian saudara-saudara Yusuf karena Yakub lebih mengasihi Yusuf (37:4), mimpi Yusuf membuat saudara-saudaranya semakin membenci dia (37:5b,8b).

3. Mimpi (חָלוֹ Khalom) menunjuk kepada Yusuf yang bermimpi (37:5a), Yusuf menceritakan mimpinya kepada keluarganya (37:6), karna mimpi Yusuf saudara-saudaranya menegur Yusuf (37:8c), Yusuf mendapat mimpi yang kedua kali dan menceritakan kepada saudarasaudaranya (37:9) dan mimpi itu juga diceritakan kepada Ayahnya (37:10).

Berdasarkan pengulangan kata-kata yang dijelaskan maka kata kunci untuk kitab Kejadian 37:1-1l adalah sebagai berikut:

1. Kata kuncinya, Israel (Yakub) lebih mengasihi Yusuf (37:3).

2. Kata kunci mengacu kepada Saudara-saudara Yusuf adalah membenci Yusuf, karena Yusuf lebih dikasihi oleh Yakub (37:4b), Yusuf mendapat mimpi dari Tuhan dan menceritakan mimpi itu kepada saudara-saudaranya (37:5b, 8b).

3. Kata kunci mengacu kepada Yusuf adalah bermimpi, Yusuf mendapat mimpi dari Tuhan dan menceritakan mimpi itu kepada keluarganya (37:5a), Yusuf meminta mereka untuk mendengarkan mimpinya (37:6), Yusuf mendapat mimpi yang pertama, tampak dalam 
mimpinya mereka sedang di ladang mengikat berkas-berkas gandum, lalu bangkitlah berkas Yusuf tegak berdiri, kemudian datanglah berkas gandum saudara-saudaranya mengelilingi dan sujud menyembah kepada berkas Yusuf (7), kedua kalinya Yusuf mendapat mimpi dari Tuhan lalu menceritakan mimpinya dimana dalam mimpi Yusuf dia melihat matahari, bulan, dan sebelas bintang sujud menyembah kepadanya (37:9), Yusuf menceritakan mimpinya kepada ayahnya dan kebencian saudara-saudaranya berubah kepada iri hati (37:10).

\section{Penokohan Dalam Kejadian 37:1-11 Keluarga Yakub}

Keluarga Yakub tinggal di tanah Kanaan. Oleh karena Yakub merupakan orang pilihan Allah meskipun Yakub anak sulung tetapi dia berhak untuk tinggal di tanah Kanaan tanah perjanjian. "Tanah Kanaan bukanlah tanah air, melainkan tanah perjanjian, tanah yang dijanjikan, tanah warisan. Orang Israel bukanlah orang asli dan pribumi, melainkan orang penumpang,"14 mereka hidup di Kanaan dengan bercocok tanam dan berternak, Yusuf dan saudara-saudaranya menjaga kambing domba milik ayahnya (37:2). Oleh karena Yusuf dilahirkan pada masa tua Yakub, ia lebih mengasihi Yusuf dan memberikan kepada Yusuf suatu jubah yang maha indah (37:3) sebagai wujud kasih sayang Yakub kepada Yusuf, "jubah yang maha indah dalam bahasa Ibrani ketonet passim. Arti ungkapan ini bisa 'beraneka warna' atau 'bertangan panjang'. Arti 'beraneka warna', passim dapat dibandingkan dengan kata Asyur paspasu, artinya 'burung yang berwarna menyala." 15 Ini menunjukkan perbedaan kedudukan atau status dari orang tua kepada anak yang paling dikasihi. Melihat Yusuf diperlakukan secara istimewa oleh ayahnya, rasa benci saudara-saudaranya diwujudkan dalam sikap mereka yang tidak menegur Yusuf dengan ramah." ${ }^{16}$

\section{Sudut Pandang Pencerita Kitab Kejadian 37:1-11}

Sudut pandang pencerita pada bagian pertama (ayat 1-2) dimulai dengan inilah riwayat keluarga Yakub yang tinggal di tanah penumpangan ayahnya yaitu tanah Kanaan, diakhiri dengan saudara-

\footnotetext{
${ }^{14}$ Walter Lempp, Tafsiran Kejadian (37-43) Kej.V/bg.l (Jakarta: BPK Gunung Mulia, 1974), 68

${ }^{15}$ Ensiklopedi Alkitab Masa Kini (Jakarta: Yayasan Komunikasi Bina Kasih/OMF, 1995), 640.

${ }^{16}$ D. L. Baker, S.M. Siahaan dan Dr. A.A. Sitompul, Pengantar Bahasa Ibrani (Jakarta: BPK Gunung Mulia, 2004), 39.
} 
saudaranya membenci Yusuf (3-4), bagian kedua (5-9) Yusuf menceritakan mimpinya kepada saudara-saudaranya dan orang tuanya tentang apa yang dialami dalam penglihatan yang terdapat dalam mimpinya serta diakhiri dengan saudara-saudaranya yang semakin dengki karena makna penglihatan yang disampaikan oleh Yusuf (10-11).

Dalam pembahasan genre ini, pencerita menekankan keadaan keluarga Yakub, saudara-saudara Yusuf yang membenci diri Yusuf, Yusuf mendapat penglihatan dalam mimpinya dan kedaulatan Allah memberikan penglihatan kepada Yusuf. Dalam ayat 5-9 pandangan pencerita terfokus kepada Yusuf mendapat mimpi, pencerita melaporkan dalam ayat (5-6) Yusuf mendapat mimpi dan menceritakan penglihatannya itu kepada saudara-saudaranya. Ayat 7-9, pencerita melaporkan bahwa Yusuf mendapat mimpi yang kedua, atas kedaulatan Allah saudara-saudara dan orang tuanya mengerti makna mimpi Yusuf. Dengan demikian, sudut pandang pencerita dalam Kejadian 37:1-11 mengacu kepada Yusuf mendapat penglihatan dalam mimpinya $(7,9)$ Yusuf menceritakan pengelihatan dalam mimpinya kepada keluarganya dan keluarganya sendiri yang mengerti makna pengelihatan dalam mimpi Yusuf (10).

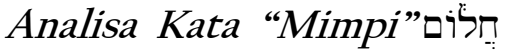 \\ Arti Harafiah}

Kata "mimpi" dalam Kejadian 37:1-11 di terjemahkan dari kata "khalome" mimpi, memimpikan, mimpi (dengan makna profetik), penglihatan dan pemimpi. ${ }^{17}$ Kata Khalome merupakan bentuk kata benda masculine, singular absolut yang berasal dari kata khalom." ${ }^{18}$ Dalam bahasa Inggris memberikan makna yang sama untuk menerjemahkan kata khalome. ${ }^{19}$ Penggunaan kata khalome dalam Perjanjian Lama yaitu alat penyataan Allah, dimana Allah menyampaikan informasi kepada umat-Nya melalui penglihatan. Jenis penglihatan atau pengungkapan ilahi Allah melalui bisa hal-hal simbolik, orang, dan tindakan. ${ }^{20}$ Dalam dunia sekitar Israel, mimpi dianggap sebagai ilham ilahi dan oleh sebab itu sebagai ramalan

\footnotetext{
version 4.

${ }^{18}$ James Strong, Strong's Exhausative Concordance of the Bible (Iowa Falls, Iowa : World Bible Publishers, n.d.), s.v. "dream."

${ }^{19}$ Strong's Concordance of the Bible, s. v. חלוֹ (accomplish, achieve) KVJ, NLT: dream, LITV: dreamed, dan ASV: dreamer. version 4 .

${ }^{20}$ Theological Wordbook of the Old Testament, Leksikon Ibrani, s.v. "khalom" Sabda
}

${ }^{17}$ Theological Wordbook of the Old Testament, Leksikon Ibrani, s.v. "khalom." Sabda 
yang dapat menentukan masa depan si-penerima mimpi." 21 "Dalam tradisi Yahudi-Kristen, makna mimpi tidaklah diragukan lagi. Mereka meyakini mimpi sebagai sarana Allah memberi petunjuk dan memimpin umat atau orang tertentu pada jalan yang ditunjukkan oleh Allah."22

Penggunaan mimpi dalam Alkitab yaitu sebagai alat bagi Allah untuk berkomunikasi kepada umat-Nya yaitu: Pertama, Allah datang kepada Laban dalam suatu mimpi dan berfirman kepadanya (Kejadian 31:24). Kedua, Allah berbicara kepada Yakub dalam mimpinya (Kejadian 28:12-13). Ketiga, TUHAN menyatakan dirinya dalam penglihatan dan berbicara dengan Musa dalam mimpi (Bilangan 12:6). Keempat, Allah berbicara kepada manusia melalui mimpi dalam penglihatan pada waktu malam (Ayub 33:15). Kelima, TUHAN berbicara memanggil nama Samuel dalam suatu penglihatan (2 Samuel 7:4). Keenam, Daniel mendapat penglihatan dalam mimpinya di tempat tidurnya (Daniel 7:1-2). Ketujuh, Zakaria mendapat suatu penglihatan dalam mimpinya (Zakaria 1:8). Kedelapan, Allah memberi penglihatan kepada Firaun (Kejadian 41:1-36). Kesembilan, Malaikat Tuhan datang kepada Yusuf dalam mimpinya (Matius 1:20-23).

Penggunaan mimpi (Khalom) dalam konteks Yusuf mendapat mimpi adalah mengandung makna profetik atau suatu penglihatan tentang nubuatan masa depan dirinya dan keluarganya. Mimpi juga dipakai oleh Allah sebagai sarana untuk berkomunikasi dengan manusia dalam menyampaikan pesan-Nya. Seperti yang ditegaskan oleh Chales A. Ver Straten bahwa "wahyu datang kepada manusia dalam dua bentuk yaitu alami dan supranatural. Karena semua orang buta secara rohani, wahyu alami gagal memberikan pengetahuan yang dapat diandalkan tentang hal yang spiritual. Untuk mengimbangi kurangnya pengetahuan, Allah mengungkapkan diri-Nya dalam wahyu supranatural." ${ }^{23}$ Melalui mimpi Allah memberitakan hal yang baik bagi umat-Nya seperti yang ada dalam penglihatan Yusuf berkas gandum milik saudara-saudaranya sujud menyembah dan matahari, bulan, serta sebelas bintang sujud menyembah kepadanya yang menandakan bahwa suatu ketika Yusuf akan menjadi pemimpin, lalu keluarganya akan sujud menyembah Yusuf. Bukan hanya hal baik yang dapat dikomunikasikan oleh Allah

\footnotetext{
${ }^{21}$ Walter Lempp, Tafsiran Kejadian (37-43) Kej.V/bg.l (Jakarta: BPK Gunung Mulia, 1974), 299.

${ }^{22}$ Fr. Teja Anthara SCJ, "Wisma Kencana,"; diakses tanggal 09 Mai 2013; tersedia http://tejaarticles.blogspot.com//

${ }^{23}$ Chales A. Ver Straten, How To Start Lay-Shepherding Ministries (Michigan, Grand Rapids: Baker Book House, 1983), 73.
} 
kepada manusia, tetapi hal-hal yang buruk pun dapat disampaikan seperti mimpi Firaun Allah menyampaikan bahwa tujuh tahun akan ada bencana kelaparan yang menimpah tanah Mesir (Kejadian 41:1-36).

\section{Struktur Kitab Kejadian 37:1-11}

A. 37:1-4 Keluarga Yakub.

1. $37: 1$ Keluarga Yakub pindah ke tanah Kanaan.

2. 37:2 Riwayat keturunan Yakub.

3. $37: 3$ Yakub memberi jubah kepada Yusuf.

4. 37:4 Saudara-saudaranya membenci Yusuf.

B. 37:5-6 Yusuf mendapat mimpi.

1. 37:5 Yusuf menceritakan mimpinya kepada saudara-saudaranya.

2. 37:6 Saudara-saudaranya mendengarkan mimpi Yusuf.

C. 37:7-9 Isi mimpi: Yusuf melihat berkas gandum milik saudarasaudaranya, matahari, bulan, dan sebelas bintang sujud menyembah kepada Yusuf.

1. $\quad$ 37:7-9 Yusuf menceritakan isi mimpinya

a. 37:7 Mimpi yang pertama: Berkas-berkas gandum Yusuf tegak berdiri, sedangkan berkas-berkas saudaranya sujud menyembah kepada berkas gandum Yusuf.

b. 37:8 Saudara-saudara Yusuf membenci Yusuf.

c. 37:9 Mimpi yang kedua: Matahari, bulan, dan sebelas bintang sujud menyembah kepada Yusuf.

D. 37:10-11 Yusuf dibenci oleh saudara-saudaranya.

1. 37:10 Yusuf ditegur oleh ayahnya, oleh karena mimpinya.

2. 37:1l Yakub menyimpan cerita itu dalam hatinya.

\section{Penjelasan Kejadian 37:1-11 \\ Keluarga Yakub}

Bagian sebelumnya menceritakan Esau meninggalkan Yakub dan pergi ke Gunung Seir, namun keluarga Yakub hidup di tanah penumpangan ayahnya tempat persinggahan, kediaman, tanah Kanaan ${ }^{24}$ Sesuai dengan perkataan berkat yang diucapkan oleh Ishak dalam Kejadian 27:33 bahwa Yakub akan diberkati.

Janji Tuhan dalam mimpi Yakub di Betel (Kejadian 28:10-22). Allah telah menggenapinya dengan membawa keluarga Yakub untuk tinggal di tanah Kanaan dan memberkati keluarga Yakub. Tanah Kanaan dijanjikan sejak zaman para leluhur bangsa Israel (Kejadian 12:3). Tuhan berjanji

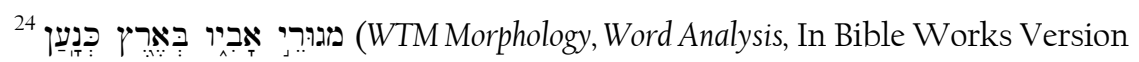


memberikan tanah untuk Abraham dan keturunannya (Kejadian 15:8), janji ini juga berlaku kepada Ishak (Kejadian 26:3) dan berlanjut kepada Yakub. "Tanah diberikan supaya umat memiliki relasi yang permanen dengan Tuhan. Tanah merupakan bukti adanya hubungan istimewa itu." ${ }^{25}$ William A. Dyrness mengatakan bahwa sebuah bangsa tidak dapat hidup tanpa tanah, tempat khusus dimana mereka dapat mengungkapkan diri mereka dan menyembah Tuhan." ${ }^{26}$

\section{Yakub Memberi Jubah Kepada Yusuf}

Yusuf menjadi anak kesayangan ayahnya tetapi Yakub tetap menyuruh Yusuf untuk menggembalakan kambing domba, untuk mengajarkan Yusuf untuk bekerja keras, hal ini juga ditegaskan oleh R.A. Jaffray menyatakan bahwa "kasih yang sehat ditunjukkan oleh orang tua kepada anak yaitu menyuruh anaknya belajar bekerja sehingga anak itu tidak manja." ${ }^{27}$ Yusuf melaporkan kejahatan saudara-saudaranya kepada ayahnya, tetapi tidak dijelaskan kejahatan apa yang dilakukan oleh mereka. Kata "kejahatan" yang dipakai disini ialah רָָָָ $r a^{\prime 28}$ artinya menunjuk kepada karakter atau tingkah laku yang jahat atau buruk. Saudara-saudaranya memiliki sifat yang buruk, sakit hati, tidak menyukai Yusuf atau bersikap jahat, sehingga membuat Yusuf mengambil tindakan untuk melaporkan kejahatan mereka kepada ayahnya. Sikap Yusuf ini juga menegur mereka supaya tidak semakin jatuh ke dalam dosa. Walaupun Yusuf masih sangat muda ia mampu menunjukkan karakter yang baik di antara kakak-kakaknya.

Yakub lebih mengasihi Yusuf kata yang digunakan mengasihi ialah " אוָ - ahav, (qal perfect orang ketiga maskulin tunggal) kasih sayang yang digambarkan seperti kasih sayang antara suami dan istri, bapak dan anak, dan hubungan persahabatan." ${ }^{29}$ John Gill mengatakan bahwa jubah yang diberikan kepada Yusuf merupakan lambang dari berbagai karakter kebaikan yang muncul dari dalam dirinya, karena karakter Allah ada didalam diri Yusuf. ${ }^{30}$

\footnotetext{
${ }^{25}$ Yongky Karman, Bunga Rampai Teologi Perjanjian Lama (Jakarta: BPK Gunung Mulia, 2009), 80

${ }^{26}$ William A. Dyrness, Agar Bumi Bersukacita (Jakarta: BPK Gunung Mulia, 2001), 59.

${ }^{27}$ Ibid.

${ }^{28}$ e-Sword, Hebrew Old Testament, s.v. "ra'a".

אהבב (WTM Morphology, Word Analysis, In Bible Works Version 7).

${ }^{30}$ John Gill's, Exposition of the Entire Bible, e-Sword.
} 


\section{Yusuf Mendapat Mimpi}

\section{Yusuf Menceritakan Mimpinya Kepada Saudara-Saudaranya}

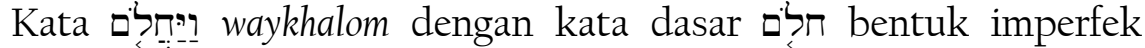
orang ketiga maskulin tunggal dengan awalan penghubung ? "31 adalah preposisi keterangan penghubung "dan tetapi, maka, lalu." ${ }^{32}$ Kata waykhalom berarti mengacu kepada suatu keadaan yang sudah terjadi yaitu menunjuk kepada Yusuf yang telah bermimpi. Matthew Henry menegaskan bahwa "mimpi yang dialami oleh Yusuf bersifat nubuatan,"33 dalam penglihatannya itu terlihat mereka sedang berada diladang, lalu berkas gandum miliknya berdiri tegak lalu berkas-berkas gandum milik saudaranya sujud menyembah kepada berkas gandum Yusuf (37:7). Mimpi di zaman kuno banyak diperhatikan tetapi mimpi Yusuf dipertimbangkan oleh keluarganya karena bersifat simbolis. Artinya mudah dicerna dan diulang di bawah lambang yang berbeda Kejadian 4l:32b hal itu telah ditetapkan oleh Allah dan Allah akan segera melakukannya. Penglihatan Yusuf ini membangkitkan kecemburuan saudara-saudaranya karena dalam penglihatannya berkas gandum milik merekalah yang akan sujud menyembah kepada berkas gandum milik Yusuf.

Ayat 6 Yusuf meminta saudara-saudaranya mendengarkan mimpinya tentang mereka. Walaupun Yusuf tidak menyadari bahwa hal yang terjadi dalam mimpinya itu adalah supernatural namun Yusuf yakin bahwa mimpi yang ia terima merupakan alat komunikasi Allah kepada Yusuf untuk menyampaikan visi Allah bagi Yusuf. "Mimpi merupakan pengalaman yang menakutkan dan menggembirakan untuk manusia pada masa kuno, karena mimpi itu dianggap sebagai tanda ajaib yang memberitahukan rahasia Allah tentang masa depan dan yang menentukan masa depan manusia." ${ }^{34} \mathrm{Hal}$ ini juga membuat saudaranya makin benci Yusuf karena hal yang dilihat Yusuf dalam penglihatannya adalah tentang masa depan saudara-saudaranya yang akan sujud menyembah kepada Yusuf.

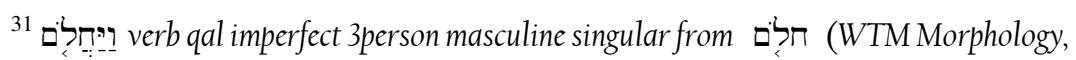
Word Analysis, In Bible Works Version 7).

32 Ibid., 195.

${ }^{33}$ Matthew Henry's, Commentary on the Whole Bible, e-Sword.

${ }^{34}$ Walter Lempp, Tafsiran Kejadian (37-43) Kej.V/bg.l (Jakarta: BPK Gunung Mulia, 1974), 75 .
} 


\section{Nubuat Allah Bagi Yusuf Dan Keluarganya, Yusuf Menjadi Pemimpin Mimpi Pertama}

Berkas-berkas gandum Yusuf Tegak Berdiri, sedangkan berkasberkas gandum saudaranya sujud menyembah kepada berkas gandum Yusuf. Dalam mimpi Yusuf tampak kepadanya mereka sedang mengikat berkas-berkas gandum di ladang lalu berkas gandum milik Yusuf bangkit. Biasanya diterjemahkan bangun berarti bangkit tetap "Firman Allah kita tetap bangkit untuk selama-lamanya" (Yesaya 40:8). Kata berarti dalam penglihatannya berkas gandum Yusuf bangkit atau tetap berdiri kemudian berkas gandum milik saudara-saudaranya datang mengelilingi lalu sujud menyembah kepada berkas gandum milik Yusuf. Menurut Walter Lempp gandum yang diikat dahulu itu berbaring (terletak) di atas tanah, barulah kemudian (untuk mengeringkan jeraminya) ditegakkan, sehingga berdiri." ${ }^{35}$ Tetapi berbeda dengan hal yang terjadi dalam penglihatan Yusuf berkas gandumnya dengan sendirinya bangkit. "Gandum dalam bahasa Ibrani dagan, gandum adalah jenis rumput yang menghasilkan biji-bijian yang sangat penting sebagai makanan manusia sejak masa purba. Karena pentingnya sebagai makanan maka gandum dijadikan lambang kebajikan dan pemeliharan Allah." ${ }^{36}$ Ini berarti mimpi yang dialami Yusuf suatu nubuatan yang menunjukkan bahwa Allah akan memelihara masa depan Yusuf dan saudara-saudaranya akan memberi hormat atau menundukkan diri kepadanya.

Berkas gandum miliknya berdiri sendiri, menurut R.A. Jaffray ini nubuat bagi Yusuf sendiri yang dahulunya direndahkan tetapi kemudian akan bangkit menjadi seorang raja, sehingga semua saudara-saudaranya datang dan sujud menyembah kepada Yusuf," ${ }^{37}$ berkas gandum juga melambangkan bahwa saudaranya datang kepada Yusuf di Mesir untuk mengambil gandum ketika mereka dilanda kelaparan.

\section{Mimpi Kedua}

Alkitab menyebut pengaruh matahari secara alami, seperti membuat tumbuh-tumbuhan bertumbuh (Ulangan 33:14, 2 Samuel 23:4), membuat layu suatu tumbuhan yang tidak berakar (Matius 13:6)." 38 Yusuf melihat bulan menyembah kepadanya, dan bukan hanya matahari,

\footnotetext{
${ }^{35}$ Lempp, Tafsiran Kejadian (37-43) Kej.V/bg.l, 77.

${ }^{36}$ Ensiklopedi Alkitab Masa Kini (Jakarta: Yayasan Komunikasi Bina Kasih/OMF,

${ }^{37}$ R. A. Jaffray, Tafsiran Kitab Kejadian, Jilid II (Bandung: Kalam Hidup, 1968), 18.

${ }^{38}$ Ibid., 35.
} 1995), 326 
bulan yang menyembah Yusuf, namun sebelas bintang sujud menyembah kepada Yusuf. Benda ini melambangkan orang tua dan saudarasaudaranya akan merendahkan diri, memberi hormat kepada Yusuf, seperti yang dikatakan oleh Walter Lempp bukan hanya saudaranya, melainkan juga orang tuanya akan mengakui kedudukannya selaku pemimpin, selaku orang yang diistimewakan di antara saudarasaudaranya." ${ }^{39}$

\section{Saudara-Saudaranya Iri Kepada Yusuf}

Yusuf Di Tegur oleh Ayahnya Karena Mimpinya

Yusuf menceritakan mimpinya yang pertama hanya kepada saudara-saudaranya. Dalam penglihatan yang kedua ia menceritakan kepada saudara-saudaranya dan ayahnya, setelah Yusuf menceritakan isi penglihatannya kepada mereka Yakub pun meresponi cerita Yusuf dengan memberi pertanyaan mimpi apa mimpimu itu? Seolah-olah Yakub ragu akan penglihatan yang Yusuf terima.

Setelah keluarganya mendengar cerita Yusuf maka iri hatilah saudara-saudaranya. Yakub diam-diam menyimpan perkataan Yusuf dalam hatinya sambil merenungkan makna mimpi Yusuf yang menunjukkan masa depan Yusuf dan keluarga Yakub yang akan sujud menyembah kepada Yusuf.

\section{RELEVANSI MIMPI DALAM KEHIDUPAN ORANG PERCAYA MASA KINI}

\section{Mimpi Sebagai Sarana Komunikasi Allah}

Mimpi adalah salah satu sarana bagi Allah untuk berkomunikasi kepada umat-Nya, baik itu pada zaman dulu maupun zaman sekarang Allah masih bisa memakai mimpi sebagai sarana komunikasi untuk menyatakan kehendak-Nya bagi umat manusia sehingga manusia lebih mengenal kemahakuasaan Allah sebagai sang pencipta. Bukan suatu hal yang aneh Allah berkomunikasi melalui mimpi kepada manusia, dalam Perjanjian Lama Allah sering berkomunikasi kepada manusia baik secara langsung seperti yang dialami oleh Musa di Gunung Sinai (Keluaran 19:16-20), dengan tegas Allah menyampaikan kepada Miryam dan Harun bahwa melalui penglihatan dan mimpi bisa dipakai-Nya sebagai sarana untuk berkomunikasi kepada Musa (Bilangan 12:6). Melalui nabi-nabi

${ }^{39}$ Walter Lempp, Tafsiran Kejadian (37-43) Kej.V/bg.l (Jakarta: BPK Gunung Mulia, 
tertentu Allah berkomunikasi untuk menyampaikan pesan-Nya seperti, Allah berkomunikasi kepada Abraham, Allah menyampaikan bahwa bangsa Israel akan diperbudak (Kejadian 28:12; 31:10-11). Allah berkomunikasi melalui mimpi kepada Yakub di Betel. Dalam mimpinya Yakub menyaksikan tangga menuju surga dengan naik keatasnya. Di puncak tangga berdirilah Allah, bahwa Allah berjanji akan memberi tanah perjanjian kepada Yakub dan akan memberkati keturunan Yakub. Yeremia bermimpi dan menerima penyataan kenabiannya dari Allah (Yeremia 31:26). Allah berkomunikasi kepada Daniel dalam mimpinya, Daniel melihat empat makhluk yang melambangkan kerajaan-kerajaan dunia yang akhirnya akan ditumbangkan oleh Anak Manusia (Daniel 7).

Bentuk komunikasi Allah dalam Perjanjian Lama dapat juga kita lihat dalam Perjanjian Baru Allah tetap menggunakan mimpi sebagai sarana untuk berkomunikasi kepada manusia. Allah berkomunikasi langsung kepada rasul-rasul-Nya melalui mimpi untuk menyampaikan rencana-Nya bagi manusia, bahkan dalam mimpi pun Ia menyatakan rencana-Nya tentang diri-Nya sendiri hadir dalam dunia dalam diri Yesus Kristus untuk menebus dosa manusia, hal ini dapat kita lihat dalam injil-injil dan surat Paulus, seperti: Mimpi Yusuf yang pertama Allah menyuruh malaikat datang kepada Yusuf untuk mengungkapkan bahwa Yusuf tidak perlu takut mengambil Maria sebagai istrinya karena anak yang dikandungnya adalah dari Roh Kudus (Matius 1:20). Setelah Yesus lahir, seorang malaikat memperingatkan Yusuf dalam mimpi untuk membawa Maria dan bayi Yesus melarikan diri dari Mesir untuk menghindari Herodes (Matius 2:13). Mimpi ketiga berlangsung setelah Herodes mati. Seorang malaikat memerintahkan Yusuf untuk pulang ke Israel bersama keluarganya karena sekarang keadaannya sudah aman (Matius 2:19-20). Tuhan berfirman kepada Paulus dalam suatu penglihatan (Kisah Para Rasul 18:9). Allah datang memperingatkan orang-orang Majus supaya tidak kembali kepada Herodes (Matius 2:12). Saat pengadilan Yesus di hadapan Pilatus, gubernur Roma ini menerima peringatan dari istrinya, Allah menyingkapkan diri-Nya dalam mimpi (Matius 27:19).

Mimpi sebagai sarana komunikasi Allah kepada umat-Nya, komunikasi-Nya tidak bisa dibatasi hanya pada Perjanjian Lama dan Perjanjian Baru, namun saat ini pun Allah dapat memakai sarana mimpi sebagai komunikasi kepada manusia di zaman sekarang bentuk dan cara yang digunakan Allah pun sama hanya mimpi yang diterima itu perlu diuji apakah mimpi itu berasal dari Allah atau dari roh jahat. Contoh, ketika Allah hendak memperingati seseorang yang hidupnya penuh dosa, Allah dapat menggunakan mimpi untuk berkomunikasi pada orang 
tersebut, tentunya orang tersebut perlu menguji mimpi yang diterimanya dengan berdoa dan menceritakan pada orang yang memiliki karunia menafsirkan mimpi. Mimpi sebagai sarana komunikasi Allah di zaman sekarang mengandung isi dan tujuan yang sama baik dalam Perjanjian Lama maupun dalam Perjanjian Baru. Allah berkomunikasi pada manusia untuk menyatakan dua hal penting:

\section{Untuk Memperingati}

Mimpi datang kepada manusia untuk menyampaikan hal-hal yang akan terjadi dan memberi peringatan kepada umat-Nya. Allah dapat menggunakan mimpi untuk memperingati seseorang yang hidupnya tidak benar dihadapan Allah. Abimelekh adalah seorang yang tidak taat kepada Allah, melalui mimpi pada waktu malam Allah datang kepadanya untuk memperingati Abimelekh bahwa perempuan yang jadi istrinya sudah bersuami, Allah mengingatkan Abimelekh untuk mengembalikan (Kejadian 20;3-7). Laban pun demikian Allah datang kepadanya dalam mimpi, untuk memperingati Laban supaya jangan mengatai Yakub dengan sepatah kata pun (Kejadian 31:24). Hal yang sama juga telah dialami oleh Chuck Pierce seorang pemimpin doa organisasi Generals of Intercession. Ia mendapatkan suatu penglihatan tentang kota Houston Texas bahwa pada tanggal 21 September 1994 ia melihat dalam penglihatannya tampak api ada di atas kota itu. Allah mengingatkan gereja-gereja untuk berjaga-jaga dan berdoa bagi kota Houston, penglihatan ini nyata terjadi ketika sungai itu meluap membanjiri kota itu, dan nyata ada api yang menyala di tengah-tengahnya. ${ }^{40}$ Melalui peringatan-peringatan yang disampaikan oleh Allah bertujuan untuk kemuliaan nama-Nya, seperti yang dikatakan oleh Jim W.Goll, "tujuan Allah berkomunikasi kepada umat-Nya dalam memberi peringatan yaitu untuk melindungi umat-Nya dan mendatangkan kemuliaan bagi namaNya." ${ }^{41}$ Penyataan ini berarti tujuan Allah berkomunikasi kepada manusia melalui mimpi-mimpi tertentu baik adanya.

\section{Untuk Penyampaian Maksud Allah}

Tuhan menyampaikan maksudnya secara luas kepada manusia, sehingga manusia lebih mengetahui kehendak Allah bagi diri si penerima mimpi maupun bagi orang yang dimimpikan. Sebagai orang percaya kita memerlukan orang untuk menafsirkan mimpi atau informasi yang diterima karena menurut Jim W.Goll, "mimpi atau penglihatan itu

\footnotetext{
${ }^{40}$ Cindy Jacobs, Suara Tuhan (Jakarta: Metanoia, 2005), 222.

${ }^{41}$ Jim W. Goll, The Seer Sang Pelihat (Jogyakarta: ANDI, 2006), 131.
} 
bersumber dari tiga hal yaitu, alam roh jahat, alam kejiwaan (pikiran dan roh manusia kita sendiri) dan Roh Kudus.. ${ }^{42}$ Dalam hal inilah karunia membeda-bedakan roh diperlukan, baik bagi si penerima mimpi maupun informasi-informasi yang diterima mengenai mimpi. Ketika menerima mimpi, pesan dalam mimpi itu perlu diuji, jika mimpi itu bertentangan dengan prinsip-prinsip firman Allah tentunya mimpi itu berasal dari roh jahat misalnya, seorang istri bermimpi bahwa ia akan menikah lagi dan seseorang bermimpi bahwa Tuhan datang kepadanya menyuruh dia bunuh diri, hal ini tentu berasal dari roh jahat. Sebaliknya jika pesan dari mimpi yang diterima mengarahkan kita kepada prinsip-prinsip firman Allah bisa dipastikan bahwa mimpi itu berasal dari Roh Kudus. Penyampaian maksud Allah melalui mimpi bisa bersifat:

\section{Bersifat Individual}

Allah menyampaikan maksudnya kepada manusia secara individual seperti Allah menyampaikan suatu nubuatan kepada Yusuf dengan memberikan penglihatan yang jelas kepada Yusuf, yaitu Allah memperlihatkan kepada Yusuf bahwa berkas gandumnya tegak berdiri lalu berkas-berkas gandum milik saudara-saudaranya mengelilingi dan sujud menyembah kepadanya, matahari, bulan dan sebelas bintang sujud kepadanya, tentunya Allah bermaksud untuk menyampaikan bahwa masa depan Yusuf akan berkuasa atas keluarganya dan keluarganya sujud menyembah kepada Yusuf.

Nubuatan yang dialami Yusuf ini tergenapi yaitu ketika Yusuf menjadi pemimpin dan menyelamatkan keluarganya dari bencana kelaparan. Allah berdaulat atas kehidupan Yusuf dengan memberikan penglihatan kepada Yusuf dengan maksud memberitahukan bahwa Yusuf akan dipakai Allah menjadi pemimpin.

\section{Bersifat Umum}

Allah menyampaikan maksudnya kepada manusia secara umum seperti yang dinyatakannya kepada Firaun dimana ia bermimpi mengenai masa depan bangsanya yang mana mereka akan mengalami kelaparan selama tujuh tahun lamanya Kejadian 4l. Allah menyatakan maksudnya kepada manusia secara umum juga, pernah dialami oleh Gideon ketika ia memenangkan peperangan dengan jumlah tentara yang hanya tiga ratus orang saja, dimana salah seorang dari tentara Midian bermimpi bahwa tampak sekeping roti jelai terguling masuk ke perkemahan orang Midian setelah sampai ke kemah ini dilanggarnya

\footnotetext{
${ }^{42}$ Goll, The Seer Sang Pelihat, 144.
} 
kemah ini, sehingga roboh, dan dibongkar-bangkirkannya, demikianlah kemah itu habis runtuh Hakim-Hakim 7:13. Mimpi yang diterima itu berarti kehancuran bangsa Midian dan kemenangan diperoleh Gideon bersama tentaranya. Mimpi yang bersifat umum yang dimaksud disini, ketika seseorang bermimpi lalu pesan dalam mimpi yang diterimanya itu untuk kepentingan orang banyak entah untuk jemaatnya, kotanya, bangsanya atau untuk dunia ini. Contoh, Allah menghendaki sebuah jemaat untuk bertobat, Allah dapat menggunakan seseorang untuk memperingati jemaat tersebut melalui mimpi.

\section{Mimpi Sebagai Sarana Penyataan Visi}

Mimpi dapat digunakan oleh Allah untuk menyatakan visi-Nya bagi orang-orang tertentu yang mengalami mimpi dengan memperlihatkan masa depannya seperti yang dialami oleh Yusuf melalui pengelihatan dalam mimpinya Allah menyatakan visi bagi masa depan Yusuf untuk menjadi seorang pemimpin bagi keluarganya bahkan bagi bangsa Mesir. Allah menyatakan visi bagi Yusuf melalui mimpi yang menunjukkan bahwa suatu hari dia akan menjadi pemimpin. Visi yang dialami dalam penglihatannya Yusuf diberi suatu gambaran yang jelas akan masa depannya, meskipun visi akan masa depan ini tidak diterima oleh kakak-kakaknya. Hal ini perlu bagi seorang pemimpin seperti Yusuf karena visi yang dinyatakan oleh Allah dapat memperjelas tujuan dan kehendak Allah bagi masa depan Yusuf. Daniel Ronda mengatakan bahwa dengan visi pemimpin secara jelas dapat melihat masa depan yang diinginkan Allah dan melangkah dalam agenda-Nya. ${ }^{43}$ Allah dapat menyatakan visi kepada seseorang melalui mimpi, ada banyak kesaksian orang yang mengalami penglihatan yang akhirnya menjadi visinya, seperti yang dialami oleh Cindy Jacobs dalam penglihatannya Allah memberitahukan bahwa Allah ingin Cindy memikul salib-Nya dan mengikuti Allah. Allah memanggil Cindy untuk membawa Injil kepada bangsa-bangsa di dunia. ${ }^{44}$ Setiap orang memerlukan visi untuk menopang kehidupan mereka. Visi akan sangat mempengaruhi kehidupan seseorang seperti yang dialami oleh William Blake, seorang seniman dan penyair yang ternama di Inggris, ia seorang visioner yang kemudian visionernya itu sangat mempengaruhi karya-karyanya. ${ }^{45}$ Allah telah menaruh visi dalam diri setiap orang, entah visi apa yang sudah Allah taruh dalam diri orang itu yang pasti bahwa janji Allah pada setiap

\footnotetext{
${ }^{43}$ Daniel Ronda, Leadership Wisdom (Bandung: Kalam Hidup, 2011), 19.

${ }^{44}$ Cindy Jacobs, Suara Tuhan (Yogyakarta: ANDI, 2005), 11.

${ }^{45}$ Jim W. Goll, The Seer Sang Pelihat (Yogyakarta: ANDI, 2006), 44.
} 
kita orang percaya itu pasti akan digenapi-Nya. Terkadang janji Allah itu muncul melalui kesaksian roh yang tenang pada waktu tertentu, melalui mimpi atau penglihatan. Namun janji itu dapat dinyatakan oleh Allah secara langsung atau melalui seseorang yang menyampaikan kepada orang tersebut. Zaman sekarang melalui mimpi Allah menyatakan visi bagi orang-orang percaya, melalui pengarahan dan pimpinan yang diberikan melalui visi yang di nyatakan dalam mimpi, visi membuat kita sebagai orang percaya tidak salah dalam melakukan kehendak-Nya.

\section{PENUTUP}

\section{Kesimpulan}

Berdasarkan hasil uraian penulis dalam karya ilmiah tentang tinjuan teologis tentang mimpi berdasarkan kitab Kejadian 37:1-1l dan relevansinya dalam kehidupan orang percaya masa kini, maka penulis menarik kesimpulan sebagai berikut:

Pertama, mimpi adalah alat penyataan Allah, di mana dalam penglihatan itu Allah menyampaikan informasi, memberikan petunjuk dan memimpin umat-Nya kepada jalan yang Allah kehendaki. Penglihatan dalam mimpi yang diberikan oleh Allah bisa dalam bentuk simbol-simbol, orang, dan tindakan.

Kedua, Allah berkomunikasi kepada manusia bukan hanya kepada orang-orang dalam Perjanjian Lama, tetapi zaman sekarang pun Allah masih menggunakan mimpi sebagai sarana untuk berkomunikasi kepada manusia untuk memperingati dan menyampaikan maksud Allah kepada manusia.

Ketiga, Allah berbicara kepada manusia dalam mimpi, sehingga manusia lebih mengenal bahwa Allah berdaulat memberikan informasi tentang masa depan seseorang.

Keempat, melalui penglihatan, Allah memberikan peringatanperingatan kepada manusia. Memperingati orang-orang tertentu yang hidupnya tidak berkenan kepada Allah, sehingga orang tersebut bertobat. Melalui peringatan-peringatan yang disampaikan oleh Allah tujuannya untuk kemuliaan nama-Nya.

Kelima, mimpi dapat digunakan oleh Allah untuk menyatakan visi bagi orang-orang tertentu dengan memberikan suatu penglihatan akan masa depannya 


\section{KEPUSTAKAAN}

Alkitab

Alkitab. Lembaga Alkitab Indonesia, 2001.

Alkitab Penuntun Hidup Berkelimpahan. Malang:Gandum Mas, 2005.

Kamus

BMG Morphology, Word Analysis. In Bible Work Version 7.

Hebrew Old Testament. e-Sword

Kamus Besar Bahasa Indonesia Jakarta: Balai Pustaka, 1994.

Strong, James. Strong's Exhausative Concordance of the Bible. Iowa Falls, Iowa :

World Bible Publishers, n.d.

Theological Wordbook of the Old Testament, Leksikon Ibrani, Sabda version 4.

\section{Ensiklopedi}

Ensiklopedi Alkitab Masa Kini Jilid I Jakarta: Yayasan Komunikasi Bina Kasih, 1995.

Ensiklopedi Alkitab Masa Kini Jilid II Jakarta: Yayasan Komunikasi Bina Kasih, 1995.

\section{Buku-buku}

Anderson, Capel Janice, and Moore Stepen. Marks \& Method: New Appraocher in Biblical Studies Chattanooga: Precept Ministries, 1992.

Baker, D. L. et al. Pengantar Bahasa Ibrani. Jakarta: BPK Gunung Mulia, 2004.

Culpepper, Alan. Hermeneutics for Preaching: Approaches to Contemporary Interprations for Preaching. Nashville: Broadman Press, 1992.

Dyrness, William A. Agar Bumi Bersukacita. Jakarta: BPK Gunung Mulia, 2001.

Goll, Jim W. The Seer Sang Pelihat. Yogyakarta: ANDI, 2006.

Jaffray, R. A. Tafsiran Kitab Kejadian, Jilid II. Bandung: Kalam Hidup, 1968.

Jacobs, Cindy. Suara Tuhan. Jakarta: Metanoia, 2005.

Kaiser, Jr. Walter. Berkhotbah dan Mengajar dari Perjanjian Lama. Bandung: Yayasan Kalam Hidup, 2009.

Karman, Yongky. Bunga Rampai Teologi Perjanjian Lama. Jakarta: BPK Gunung Mulia, 2004. 
Lempp, Walter. Tafsiran Kejadian (37-43) Kej.V/bg.l. Jakarta: BPK Gunung Mulia, 1974.

Park, Sun Yune. Tafsiran Kitab Kejadian. Batu Malang: YPPI, 2002.

Pratt, Jr. Richard L. Ia Berikan Kita Kisah-Nya. Surabaya: Momentum, 2005.

Ronda, Daniel. Leadership Wisdom. Bandung: Kalam Hidup, 2011.

Charles, StratenVer A. How To Start Lay-Shepherding Ministries. Michigan, Grand Rapids: Baker Books House, 1983.

Utley, Bob. Anda Dapat Memahami Alkitab Keunggulan Perjanjian Baru: Wahyu Texas Bible Lesson Internasional, Marsall, 1999.

\section{Artikel Internet}

Domhoff, G. William. "Dreamsearch," diakses tanggal 09 April 2013; tersedia di http"//www.ucsc. edu/dreams/library/purpose.html.

SCJ Anthara, Teja Fr. "Wisma Kencana,"; Diakses tanggal 09 Mai 2013; tersedia http://tejaarticles.blogspot.com/ 